\title{
Kadın Futbolcularda 12 Haftalık Kettlebell Antrenmanlarının Bazı Fiziksel ve Fizyolojik Parametreler Üzerine Etkilerinin İncelenmesi*
}

\author{
Büșra ÖZTÜRK' ${ }^{1}$, Murat TAŞ ${ }^{1+}$ (ID \\ ${ }^{1}$ Manisa Celal Bayar Üniversitesi, Spor Bilimleri Fakültesi, Manisa.
}

Orijinal Makale

Gönderi Tarihi: 17.07.2020
Kabul Tarihi: 04.09.2020

DOI: $10.25307 / j s s r .770964$

Online Yayın Tarihi: 31.12.2020

\section{Öz}

Bu çalışmada, kadın futbolcularda 12 haftalık kettlebell antrenmanlarının bazı fiziksel ve fizyolojik parametrelerinin zamana bağlı süreçteki etkilerinin incelenmesi amaçlanmıştır. Araştırmaya, düzenli antrenmanlara ve müsabakalara katılan 17-25 yaş arasında, denek grubu $(\mathrm{n}=15)$, kontrol grubu $(\mathrm{n}=15)$ olan 30 lisanslı kadın futbolcu gönüllü olarak katılmıştır. Denek ve kontrol gruplarının; sağ/sol el pençe kuvveti, bacak ve sırt kuvveti, esneklik, dikey sıçrama, vücut ağırlıkları, vücut yağ ve kas miktarı, VKİ, $\mathrm{VO}_{2}$ maks, çeviklik ve sürat değerleri ön test ve son test olarak analiz edilmiş̧ir. Çalışmadan elde edilen verilerin analizi için SPSS 25.0 istatistik paket programı kullanılmıştır. Deney ve kontrol gruplarının kendi içlerindeki karşılaştırılmalarında Eşleştirilmiş Örneklem t-Testi (Paired Sample t-Test), iki grubun karşılaştırılmasında ise Bağımsız Örneklem t-Testi (Independent Sample T-Test) yapılmıştır. Katılımcıların tanımlayıcı verileri minimum, maksimum, ortalama ve standart sapma değerleri gösterilmiştir. Anlamlılık değeri istatistiksel olarak $\mathrm{p}<0,05$ olarak kabul edilmiştir. Denek grubun demografik bilgileri Yaş: $21,00 \pm 2,00$ yıl, Boy: 1,65 $\pm 0,03 \mathrm{~cm}$ ve Spor yaş1: $11,87 \pm 2,00 \mathrm{y} 1$, kontrol grubunun demografik bilgileri Yaş: $20,00 \pm 2,25$ y1l, Boy: 1,63 $\pm 0,04 \mathrm{~cm}$ ve Spor yaşı: 10,47 $\pm 1,60$ yıl olarak tespit edilmiştir. Her iki grubunda karşılaştırma sonuçları incelendiğinde 12 haftalık kettlebell antrenman programının sonunda sırt ve bacak kuvveti, sağ/sol el kavrama kuvveti, dikey sıçrama, $\mathrm{VO}_{2}$ maks, çeviklik, sürat, vücut ağırlıkları ve VKİ değerlerinde istatistiksel olarak $(\mathrm{p}<0,05)$ düzeyinde anlamlı farklılıklar meydana gelmiştir. Katılımcılara 12 haftada, haftada 3 gün düzenli olarak yaptırılan kettlebell antrenman

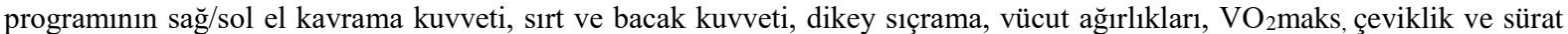
değerleri üzerinde istatistiksel açıdan anlamlı bir etkinin olduğu tespit edilmiştir.

Anahtar kelimeler: Kettlebell, Kettlebell antrenmanları, Kadın futbolu, Kuvvet, $\mathrm{VO}_{2}$ maks.

\section{Investigation of the Effects of 12-Week Kettlebell Workouts on Some Physical and Physiological Parameters in Female Football Players}

\begin{abstract}
The aim of this study is to investigate the effects of some physical and physiological parameters of 12-week- kettlebell training in female players over time. 30 voluntary female football players, ages between 17-25, participated in this research. The experimental group had 15 and the control group had 15 individuals. Experimental and control groups; right/left-hand claw strength, leg and back strength, flexibility, vertical jump, body weights, body fat and muscle amount, $\mathrm{BMI}, \mathrm{VO}_{2}$ max, agility, and speed values were analyzed as pretest and posttest. In analysis of the data obtained from the study, SPSS 25.0 statistics package program was used. Paired Sample t-Test was used for comparisons between experimental and control groups, and Independent Sample T-Test was used to compare the two groups. Descriptive data of the participants were shown as a minimum, maximum, average, and standard deviation. The demographic information of the experimental group is Age: 21.00 \pm 2.00 years, Length: $1.65 \pm 0.03 \mathrm{~cm}$, and Sports age: $11.87 \pm 2.00$ years. Demographic information of the control group is Age: $20.00 \pm 2.25$ years, Length: $1.63 \pm 0.04 \mathrm{~cm}$, and Sports age: $10.47 \pm 1.60$ years. When comparison results were examined in both groups, significant differences occurred statistically $(\mathrm{p}<0.05)$ at the end of the 12-week kettlebell training program, back and leg strength, right/left-hand grip force, vertical jump, $\mathrm{VO}_{2} \max$, agility, speed, body weights, and BMI values. Participants were found to have a statistically significant effect on the right/left handgrip force, back and leg strength, vertical jump, body weights, $\mathrm{VO}_{2} \max$, agility, and speed, which are regularly performed 3 days a week.
\end{abstract}

Keywords: Kettlebell, Kettlebell Training, Female Football, Strength, $\mathrm{VO}_{2}$ max.

\footnotetext{
* Bu çalışma, ikinci yazarın danışmanlığında yürütülen Büşra ÖZTÜRK'e ait yüksek lisans tezinden türetilmiştir.

† Sorumlu yazar: Murat TAŞ, Prof. Dr., E-posta: murattas25@gmail.com
} 


\section{GíRiș}

Futbol, dünya çerçevesinde birçok spor etkinlikleri arasında seyirci ve sporcu sayısının fazla olması ile popüler hale gelinen ve seyir zevkinin en üst düzeye taşıyan spor branşı olmaktadır. FIFA'nın (Uluslararası Futbol Federasyonu) 2014'de yayımladığı verilere göre 265 milyon futbolcu ve 5 milyon hakem aktif katılım göstermektedir (Haugen, 2014). Bu veriler sonucunda futbol, kolaylıkla ulaşılabilir olması, topluma hitap edilebilirliği ve ayrıca etkisi altında bıraktığı büyük toplumu diğer branşları arasında farklı bir yer almaktadır. Dünya üzerindeki etkisini ülkeler içerisindeki yerel liglerinde takımlar arasında yapılan müsabakalarda farklı stratejiler ve oyun içi taktiklerin gelişmesini sağlamıştır. Yerel toplumun, takımların ve oyuncuların genel amacı "gol atmak”, “ öne geçmek” olduğu için futbol müsabaka analiz çalışmalarında çoğu karşılaşmanın ofansif yönde olduğu tespit edilmiştir (Mackenzie ve Cushion, 2013).

Dünyanın en popüler spor dallarından birisi olan futbol, elit düzeydeki sporculardan beklenilen fiziksel başarılar da yüksek olmaktadır. Futbolcuların sportif başarıları ve elde ettikleri verimliliklerini birçok faktöre bağlıdır. Bu etmenler ile performans için egzersizlerde yüksek şiddeti, aralıklı yüklenmeleri, dayanıklılığı, çabuk sprintleri, top becerilerini, taktiksel gelişimini, koordinasyonları ve dengeyi kapsamıma alan bir spor dalıdır (Agostini, 1994).

Spor bilimleri alanındaki son gelişmelere göre sporun üst düzeylere taşınmasının performans değerini arttırdığ görülmektedir. Bireysel ya da takım sporlarında performans düzeylerinin artmasıyla beklenen hedeflere ulaşılması oldukça zorlaşmıştır. Gelişmekte olan bu antrenman programlarında, antrenörler yenilikçi ve farklı yollarla da geliştirilebilen antrenman yöntemlerini uygulamaktadır. Bireysel spor branşlarında olduğu gibi futbolda da antrenman yöntemlerini geliştirmekte oldukça önemlidir. Futbol antrenmanı, sporcunun performansını en üst seviyeye taşımak ve performans düzeyini korumak için planlı, programlı ve süreklilik gerektiren çalışmalardan oluşmaktadır (Günay ve Yüce, 2001).

Futbolda kondisyonel olarak sporcular kendi performanslarını geliştirerek farklı ve yenilikçi olan birçok bilimsel çalışmalara da yer verilmiştir. Antrenörler bu antrenman programlarını sporcuların performans düzeylerinin sonucuna göre geliştirmekte ve kendi stratejilerini de oluşturmaktadır. Futbol oyunu uzun süreli yüksek tempoda oynanmaktadır. Sporcuların kardiyovasküler olarak dayanıklılık antrenmanları ile kuvvet, sürat ve koordinasyon özellikleri geliştirilirken, vücut kompozisyon düzeylerini de en üst seviyeye getirmeleri gerekmektedir (Albay vd., 2008).

Futbol oyunu içerisinde sürat oldukça önemli bir yere sahiptir ve oldukça da karışıktır. Çünkü oyunun hızına, rakibin durumuna ve topun hareketliliğine göre hızlanarak ya da yavaşlayarak reaksiyonlar göstermektedir. Sürat motorik özelliği sporcunun hızı, sprint, reaksiyon sürelerini ve karar verme hızlarını geliştirmektedir. Sporcunun bu süreçler içerisinde algılama düzeyi, sentezlere ayırması ve değerlendirmesinde hızlı karar verme, ani yön değiştirmelerinde performansta en hızlı hale geliştirilmesinde önemli yer kapsamaktadır (Eniseler, 2010).

Son on y1lda futbol, anaerobik kapasitelerinin arttırılması ile uygulanan antrenman yöntemlerinin geliştirilmesi yer almaktadır. $\mathrm{Bu}$ da futbolda sayının artışında anaerobik 
performans özelliklerinin de daha önemli hale gelmesine neden olmuştur (Bizzini, Junge, Bahr ve Dvorak, 2011). Sporcuların performanslarını etkileyen diğer faktörler kuvvet, sürat, güç ve çabukluk gibi birçok motorik özelliklerde yer almaktadır. Futbolda sporcuların bu özelliklerinin yetiştirilmesi gerektiklerinin ve müsabaka sonucunda performanslarını doğrudan etkileyen faktörler arasındadır (Açıkada vd., 1996; Köklü, Özkan ve Ersöz, 2009).

Futbol diğer taraftan bakıldığında aerobik ve anaerobik gücün kullanıldığı sürat, çeviklik, denge ve esneklik gibi kassal ve kardiorespiratör faktörlerin performansa etki ettiği, aynı zamanda zihinsel olarakta kendine özgü tekniği ve taktiği olan bir spordur (Arnason vd., 2004). Çok yönlü olan sporcuların birbirlerinden etkilenen çok hızlı ve sık yapılan hareketleri, kısa sprintleri, sıçramaları, topa vurma, topla yön değiştirmeleri, markaj ve oyun içerisinde kendiliğinde gelişen daha önceden tahmin edilemeyen oyun örnekleri futbolun içerisinde yer almaktadır (Baker ve Nance, 1999; Bangsbo ve Mihalsik, 2002; Cometti vd., 2001).

Futbolda oyun esnasında toplam koşulan mesafenin \%11'ini topa sahip olmayı sağlayan yüksek hızda yön değiştirmeli koşular oluşturmaktadır (Little ve Williams, 2006). Çeviklik motorik özelliği birçok spor branşında olduğu gibi futbolda da performansı etkileyen önemli bir faktördür. Aynı zamanda bir futbol oyuncusunun ani yön değiştirmeli koşularının, ani hızlanma veya durması gibi hareketlerinin sürekliliği ve kalitesi en temel performans etkenidir ve genel olarak popülasyonuna bakıldığında elit futbolcuların kuvvet, güç, esneklik gibi diğer saha testlerinden ayırt edici olan önemli bir özelliktir (Reilly, Bangsbo ve Franks, 2000). Çeviklik bir hareket serisinin çok hızlı şekilde yön değiştirilmeleri esnasında vücudun ve eklemlerin yer çekimine karşı koyduğu doğru pozisyonda olmasını sağlayan nöronların aracılığı ile kontrol ve koordinasyon becerisidir. Futbol müsabakalarında sporcuların hızlı karar verme ve ani yön değiştirmeleri koşuları fizyolojik etmenler olarak etkilediği gibi psikolojik olarak da önemli bir yeri olmaktadır. Ayrıca bu iki etmeninde çevikliğin ana bileşenleri olarak bilinmektedir (Sheppard ve Young, 2006).

Kondisyonel özelliklerin en temeli olan kuvvet birçok spor dallarında önemli bir yere sahip olduğu gibi futbolda da oldukça önemli bir yere sahiptir (Acar, 2000). Son yıllarda "yeniden keşfedilen" tanımıyla fiziksel aktivite türlerinden biri olan, temel olarak kas gücünün ve türevlerinin dinamik gelişimi nedeniyle "CrossFit" adı altında kettlebell kullanımı ile antrenman yapılmaktadır. Bir antrenman metodu olarak bu faaliyetin içeriğinde bütünsel olarak ele alınır; diğer sporcular ve antrenörler, bar ile yapılan egzersizlerin etkilerinden gelişim sağlaması ve çok yönlü etkileri nedeniyle, kettlebell antrenmanlarını kendi antrenman programlarına dahil etmeye çalışmışlardır (Holmberg, 2009). Bu bilgiler ışı̆̆ında bu çalışma, kettlebell antrenmanlarının kadın futbolcularda bazı fiziksel ve fizyolojik parametreler üzerine etkilerinin incelenmesi amacı ile yapılmıştır.

\section{YÖNTEM}

$\mathrm{Bu}$ araştırmanın grubunu; Antalya ilinde 1. ve 2. Kadın liglerinde futbol oynayan, $17-24$ yaş arası, denek grubu (15) ve kontrol grubu (15) olan 30 gönüllü kadın katılımcı oluşturmuştur. Araştırmadan önce katılımcılara araştırmanın amaçları, uygulanacak antrenman yöntemleri, uygulanacak ölçümler ve sorumlulukları ile ilgili açıklama yapıldı. Katılımcılardan Bilgilendirilmiş Onam Formu doldurmaları istendi. 


\section{Veri Toplama Araçları}

Boy Ölçümü: Boy uzunluğu ölçümü stadiometre kullanılarak ölçülmüştür.

Antropometrik Ölçümler: Araştırmaya katılan katılımcıların vücut ağırlıkları (kg), vücut kas miktarı (\%), vücut kas ağırlı̆̆ $(\mathrm{kg})$ ve VKİ $(\mathrm{kg} / \mathrm{m} 2)$ “ "Tanita BC 418” marka biyoelektriksel impedans analizörü (BİA) kullanılarak ölçülmüştür.

Dikey Sıçrama Testi: Dikey sıçrama ölçümü için $0.1 \mathrm{~cm}$ duyarlılıkta dijital "jumpmetre" (Takei, Japan) kullanılmıştır.

El Pençe Kuvveti Testi: El-Pençe kuvveti, Takei Marka TKK 5101 Grip-D model el dinamometresi ile ölçülmüştür.

Sırt ve Bacak Kuvvet Testi: Takei marka sırt ve bacak dinamometresi kullanılarak ölçümler yapılmıştır.

20 Metre Mekik Koşusu Testi: Bu test 20 metre mekik koşu (shuttle run test) testi ile yapılmıştır.

Codat Testi: Bu test protokolünde başlangıç için bir Newtest 300 0,01 hassasiyetli fotosel, bu kapının sağ tarafına $90^{\circ}$ açıda ve 5 metre uzaklığına bir dönme noktası koyulmuştur. İlk dönme noktasının sol tarafina yine $90^{\circ}$ açıda ve 5 metre uzaklığına ikinci bir dönme noktası yerleştirilmiştir. Üçüncü dönme noktası, ikincisi dönme noktasının sağ tarafında olmak üzere $90^{\circ}$ ve 5 metre uzaklığa yerleştirilmiştir. Son dönme noktasının soluna $90^{\circ}$ olacak şekilde ikinci Newtest 300 0,01 hassasiyetli fotosel ve test için gerekli tüm ekipmanlar kurulmuş duruma gelmiştir. Sporcular başlangıç kapısının 30cm. arkasında hazır durumda beklerken, başlangıç kapısından gelen yeşil 1şık uyarısı ile teste başlamışlardır. Sporcular tüm dönme noktalarından geçiş yapmışlar, bitiş kapısından da geçerek testi sonlandırmışlardır. Sporcuları test öncesinde yapabilecekleri en yüksek hızda ve serilikte yapmaları için motive edilmişlerdir (Loturco vd., 2017).

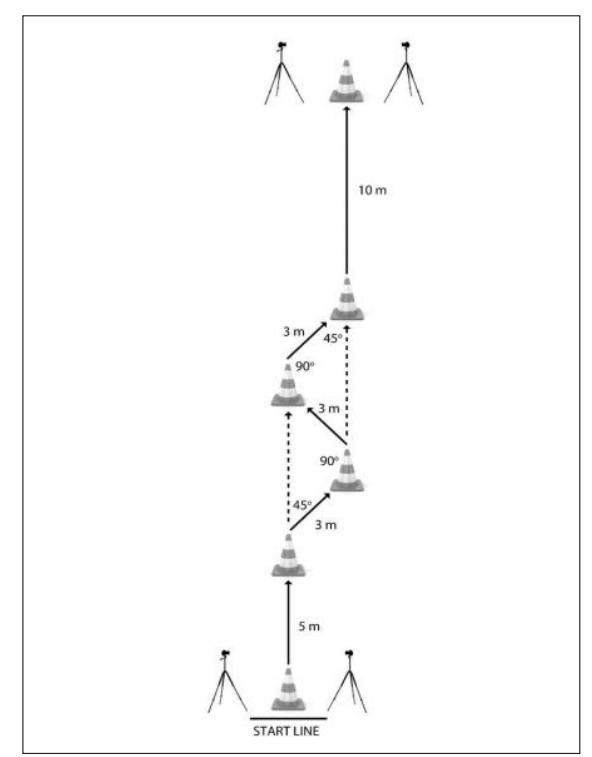

Şekil 1. Codat Testi (Zig-Zag Yön Değiştirmeli Koşu Testi) 
Pro-Agility Çeviklik Testi: 20 metre koşu testi olarak da bilinen pro-agility çeviklik test alanı (Şekil 2), başlangıç çizgisinin 5 yard $(4,57 \mathrm{~m})$ soluna ve sağına işaretçilerin yerleştirilmesi şeklinde belirlenir. Başlangıç çizgisine fotocell kapısı yerleştirilir. Tekrarlı geçiş zamanları bu sayede alınabilir. Uygulama başlamadan katılımcı başlangıç çizgisinde yerini alır. Hazır olduğunda önce sağdaki işaretçiye, sonra da soldaki işaretçiye dokunarak başlangıç çizgisinden geçerek testi sonlandırır (Bayraktar, 2013).

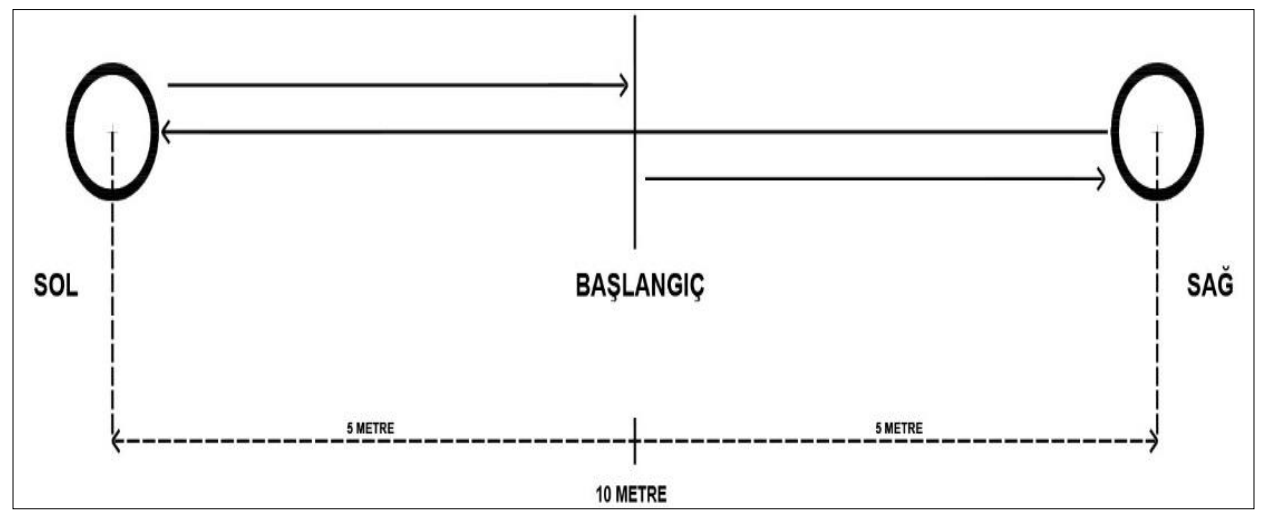

Şekil 2. Pro-Agility Testi

İllinois Çeviklik Testi: Eni $5 \mathrm{~m}$, boyu $10 \mathrm{~m}$ ve orta bölümünde $3.3 \mathrm{~m}$ aralıklarla düz bir hat üzerine dizilmiş üç koniden oluşan test parkuru kurulur (Şekil 3). Test, her 10 m'de bir $180^{\circ}$ dönüşler içeren 40 m'si düz, 20 m'si koniler arasında slalom koşusundan oluşmaktadır. Test parkuru hazırlandıktan sonra başlangıç ve bitimine 0.01 sn hassasiyetle ölçüm yapan iki kapılı fotoselli elektronik kronometre sistemi yerleştirilir. Test öncesinde deneklere parkurun tanıtımı ve gerekli açıklamalar yapıldıktan sonra düşük tempoda 3-4 deneme yapmalarına izin verilir. Bundan sonra deneklere kendi belirledikleri düşük tempoda 5-6 dk 1sınma ve germe egzersizleri yaptırılır. Denekler test parkurunun başlangıç çizgisinden, yüzüstü yatar pozisyonda ve eller omuz hizasında yerle temas halindeyken çıkış yaparlar. Parkuru bitirme zamanı saniye cinsinden kayıt edilir. Tam dinlenme ile test 2 kez tekrarlanır, iyi olan değer kaydedilir (Karacabey, 2013).

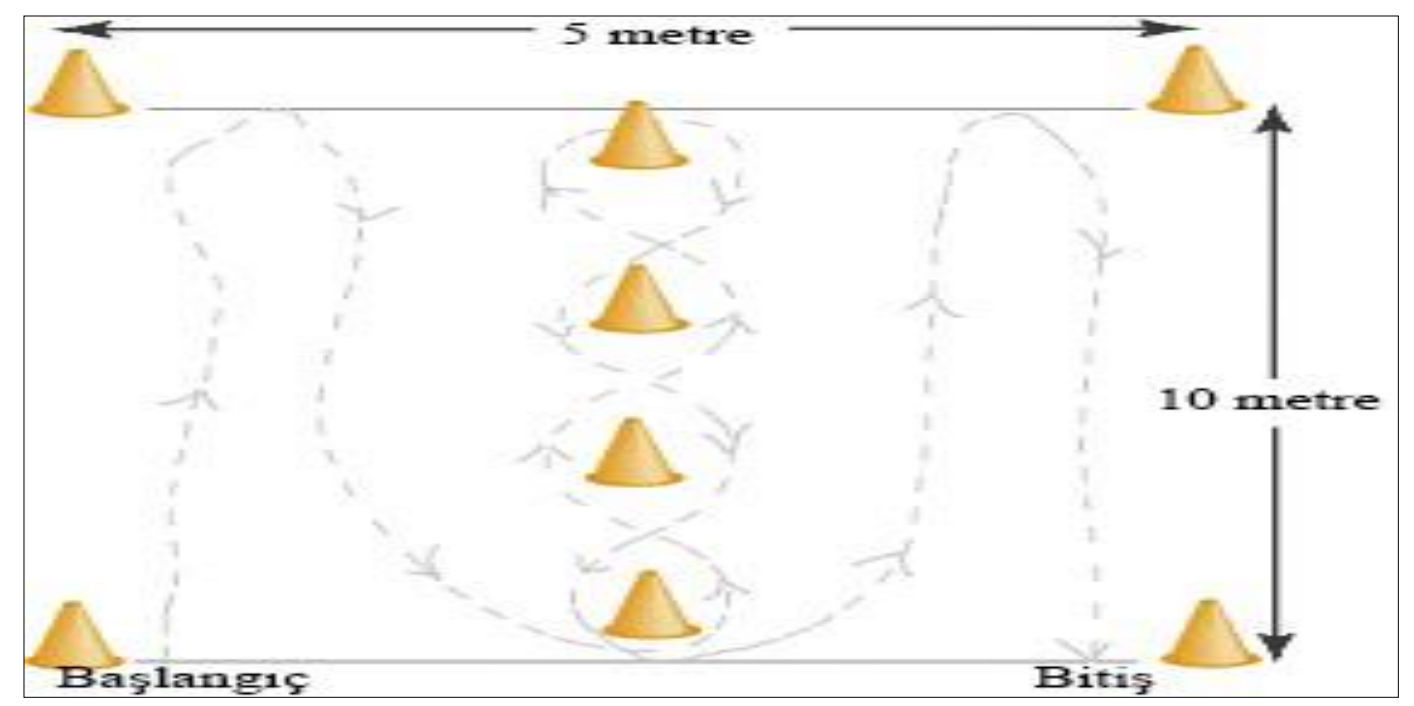

Şekil 3. Illinois Çeviklik Testi 
T Testi: Parkuru hazırlamak için yukarıdaki gibi 4 koni parkura Şekil 4'teki gibi dizilir. Katılımcı başla komutu verildiğinde "A" konisinden başlar, "B" konisine düz koşu ile koşar ve sağ eli ile koniye dokunur. Sonra sola "C" konisine doğru yan koşu (side step) ile koşup "C" konisine sol el ile dokunur, sonra sağa doğru "D" konisine yan koşarak sağ eli ile dokunur. Sonra "B" konisine yan koşu ile gelip sol el ile dokunduktan sonra "A" konisine geri koşu ile geri döner. "A" konisine gelir gelmez kronometre durdurulur. Bu çalışmada katılımcı tam dinlenme ile 3 maksimum tekrar yapar. Katılımcının en iyi olan süresi kaydedilir (Karacabey, 2013).

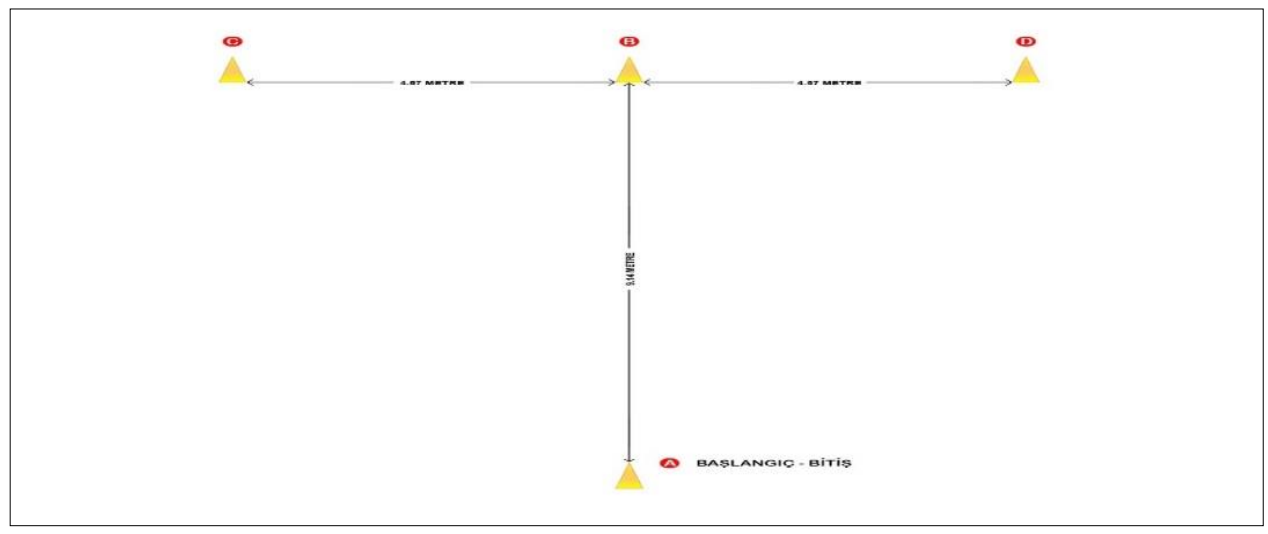

Şekil 4. T Test çeviklik testi

Sprint Testleri: Katılımcıların süratlerini belirlemek için 10 metre, 20 metre ve 30 metre sprint testleri uygulanmıştır. Bu testlerde Newtest 300 (Finlandiya) test bataryası kullanılmıştır.

Egzersiz Yöntemi: Çalışmada denek grubu 12 hafta boyunca, haftada 3gün (Pazartesi Çarşamba - Cuma), saat 17.00 - 19.00 arası, 15 dakika 1sınma 30 dakika Kettlebell antrenman programına katılmışlardır. Program table 1'de sunulmuştur.

Tablo 1. Ketllebell antrenman programı (Manocchia, Spierer, Lufkin, Minichiello ve Castro, 2013).

\begin{tabular}{|c|c|c|c|}
\hline & \multicolumn{3}{|c|}{ GÜNLER } \\
\hline & Pazartesi & Çarşamba & Cuma \\
\hline $\begin{array}{l}\text { İlk } 4 \text { Hafta } \\
(\% 60-70)\end{array}$ & $\begin{array}{l}\text { Kettlebell salıncaklar, yana } \\
\text { çömelme ve squat, kettlebell } \\
\text { ile yükselme }\end{array}$ & $\begin{array}{l}\text { Dinamik 1sınma / } \\
\text { plankhareketi, } \\
\text { kettlebelliyukarıya } \\
\text { kaldırma,kettlebell ile } \\
\text { omuzakaldırma, kettlebell ile } \\
\text { şınav çekme }\end{array}$ & $\begin{array}{l}\text { Plank hareketi ve mat } \\
\text { (pilates) topları,çömelme } \\
\text { ve transfer, deadlift }\end{array}$ \\
\hline $\begin{array}{l}\text { İkinci } 4 \text { Hafta } \\
(\% 70-80)\end{array}$ & $\begin{array}{l}\text { Plank hareketi and mat } \\
\text { (pilates) topları, çift ve tek } \\
\text { kol salıncakları, ketllebell ile } \\
\text { yel değirmeni hareketi }\end{array}$ & $\begin{array}{l}\text { Dinamik ısınma, çömelme ve } \\
\text { deadlift çift ve tek bacak } \\
\text { antrenmanı }\end{array}$ & $\begin{array}{l}\text { Kettlebell salıncakları, } \\
\text { kettlebelli yukarıya } \\
\text { kaldırmaketllebell } \\
\text { dairesel pres ve } \\
\text { kettlebell ile şınav } \\
\text { çekme }\end{array}$ \\
\hline $\begin{array}{l}\text { Son } 4 \text { Hafta } \\
(\% 80-90)\end{array}$ & $\begin{array}{l}\text { Dinamik ısınma, çift kol } \\
\text { salıncakları,kettlebell ile yel } \\
\text { değirmeni hareketi ve } \\
\text { kettlebelli omuzdan yukarıya } \\
\text { fırlatma hareketi }\end{array}$ & $\begin{array}{l}\text { Plank hareketi,Kettlebell } \\
\text { salıncakları, Turkish kalkış } \\
\text { hareketi, kettlebelli omuzdan } \\
\text { yukarıya taşıma hareketi }\end{array}$ & $\begin{array}{l}\text { Plank hareketi ve mat } \\
\text { (pilates) topları, } \\
\text { çömelme ve yana } \\
\text { çömelme, deadlift }\end{array}$ \\
\hline
\end{tabular}


Araştırma Etiği: Araştırma, Manisa Celal Bayar Üniversitesi Tıp Fakültesi Dekanlığı Sağlık Bilimleri Etik Kurulu tarafindan 26/12/2018- 20.478.486 karar numarası ile onaylandı.

\section{Verilerin Analizi}

Verilerin istatiksel analizi için IBM SPSS Statistics 25 (Statistical Package for theSocial Science) programı kullanılmıştır. Deney ve kontrol gruplarının kendi içlerindeki karşılaştırılmalarında Eşleştirilmiş Örneklem t-Testi (Paired Sample t-Test), iki grubun karşılaştırılmasında ise Bağımsız Örneklem t-Testi (Independent Sample T-Test) kullanılmıştır. $\mathrm{Bu}$ çalışmada, hatanın maksimum kabul edilebilirlik düzeyi \%95 olarak belirlenmiştir.

\section{BULGULAR}

Tablo 2. Denek grubunun tanımlayıcı parametreleri

\begin{tabular}{lcccccc}
\hline \multirow{2}{*}{ Değişkenler } & \multicolumn{2}{c}{ Ön Test $(\mathbf{n = 1 5})$} & \multicolumn{2}{c}{ Son Test(n=15) } & \multirow{2}{*}{ t } & \multirow{2}{*}{ p } \\
\cline { 2 - 5 } Yaş (Yıl) & Ort & SS & Ort & SS & & \\
Boy (cm) & 21,00 & 2,00 & 21,00 & 2,00 & & \\
Vücut Ağırlık (kg) & 1,65 & 0,03 & 1,65 & 0,03 & & \\
Spor yaşı (Yıl) & 59,15 & 6,80 & 60,23 & 6,50 & $-2,689$ & \multirow{2}{*}{$\mathbf{0 , 0 1 8 *}$} \\
VKİ (Vücut Kitle İndeksi) $\left(\mathbf{k g} / \mathbf{m}^{\mathbf{2}}\right)$ & 11,87 & 2,00 & 11,87 & 2,00 & & \\
& 21,7 & 1,80 & 22,11 & 1,71 & $-2,238$ & \multirow{2}{*}{$\mathbf{0 , 0 4 2 *}$} \\
\hline
\end{tabular}

Ort. = Ortalama; SS $=$ Standart Sapma $* \mathrm{p}<0,05$

Tablo 2 incelendiğinde, katılımcıların tanımlayıcı parametreleri gösterilmiştir. Buna göre denek grubunun yaş ortalamaları $21,00 \pm 2,00$ yıl, boy ortalamaları $1,65 \pm 0,03 \mathrm{~cm}$, spor yaş1 ortalamaları 11,87 $\pm 2,00$ yıl, vücut ağırlıkları ön test ortalamaları $59,15 \pm 6,80 \mathrm{~kg}$, vücut ağırlıkları son test ortalamaları $60,23 \pm 6,50 \mathrm{~kg}$, VKİ ön test ortalamaları $21,77 \pm 1,80 \mathrm{~kg} / \mathrm{m}^{2}$, VKİ son test ortalamaları $22,11 \pm 1,71 \mathrm{~kg} / \mathrm{m}^{2}$ dir. Karşılaştırma sonuçlarına göre 12 haftalık egzersiz sonunda vücut ağırlıkları $(\mathrm{kg})$ ve VKI $\left(\mathrm{kg} / \mathrm{m}^{2}\right)$ ortalamalarında istatistiksel olarak anlamlı farklılıklar meydana gelmiştir $(\mathrm{p}<0,05)$.

Tablo 3. Denek grubunun çeviklik test parametreleri

\begin{tabular}{lcccccc}
\hline \multirow{2}{*}{ Değişkenler } & \multicolumn{2}{c}{ Ön Test $(\mathbf{n}=\mathbf{1 5})$} & \multicolumn{2}{c}{ Son Test $(\mathbf{n}=\mathbf{1 5})$} & \multirow{2}{*}{ t } & \multirow{2}{*}{ p } \\
\cline { 2 - 5 } & Ort & SS & Ort & SS & & \\
\hline Codat Test (m/sn) & 6,24 & 0,3 & 5,81 & 0,26 & 4,027 & $\mathbf{0 , 0 0 1}^{*}$ \\
T test (m/sn) & 10,93 & 0,4 & 10,13 & 0,39 & 5,053 & $\mathbf{0 , 0 0 0}^{*}$ \\
İllinois Test (m/sn) & 17,02 & 0,57 & 15,57 & 0,74 & 5,946 & $\mathbf{0 , 0 0 0}^{*}$ \\
Pro-Agility (m/sn) & 6,25 & 0,36 & 5,66 & 0,33 & 3,974 & $\mathbf{0 , 0 0 1}^{*}$ \\
\hline
\end{tabular}

Ort. = Ortalama; $\mathrm{SS}=$ Standart Sapma ${ }^{*} \mathrm{p}<0,05$

Tablo 3 incelendiğinde, katılımcıların çeviklik testlerinin ortalamaları gösterilmiştir. Denek grubunun karşılaştırmalarına göre 12 haftalık egzersizin sonunda codat (yön değiştime) testi, $t$ Test, illinois testi ve pro-agility test sonuçlarında istatistiksel olarak anlamlı olarak farklılıklar meydana gelmiştir $(\mathrm{p}<0,05)$. 
Öztürk, B., ve Taş, M. (2020). Kadın futbolcularda 12 haftalık Kettlebell antrenmanlarının bazı fiziksel ve fizyolojik parametreler üzerine etkilerinin incelenmesi. Spor Bilimleri Araştırmaları Dergisi, 5(2), 143-158.

Tablo 4. Denek grubuna ilişkin fiziksel parametreler

\begin{tabular}{|c|c|c|c|c|c|c|}
\hline \multirow{2}{*}{ Değişkenler } & \multicolumn{2}{|c|}{ Ön Test (n=15) } & \multicolumn{2}{|c|}{ Son Test $(n=15)$} & \multirow{2}{*}{$\mathbf{t}$} & \multirow{2}{*}{$\mathbf{p}$} \\
\hline & Ort & SS & Ort & SS & & \\
\hline Sağ El Kuvveti (kg) & 23,85 & 3,29 & 28,43 & 4,45 & $-6,253$ & $0,000 *$ \\
\hline Sol El Kuvveti (kg) & 21,75 & 4,07 & 25,81 & 5,06 & $-5,789$ & $0,000 *$ \\
\hline Surt Kuvveti (kg) & 74,26 & 14,15 & 84,28 & 11,46 & $-4,908$ & $\mathbf{0 , 0 0 0 *}$ \\
\hline Bacak Kuvveti (kg) & 76,75 & 7,31 & 87,21 & 9,65 & $-5,624$ & $\mathbf{0 , 0 0 0} *$ \\
\hline Dikey Sıçrama (cm) & 37,13 & 4,22 & 42,13 & 4,27 & $-8,204$ & $0,000 *$ \\
\hline $\mathrm{VO}_{2} \mathrm{maks}(\mathrm{ml} / \mathrm{kg} / \mathrm{dk})$ & 38,24 & 5,06 & 44,81 & 4,73 & $-17,57$ & $\mathbf{0 , 0 0 0} *$ \\
\hline 10 m Sprint (m/sn) & 2,5 & 0,18 & 2,24 & 0,16 & 4,601 & $\mathbf{0 , 0 0 0} *$ \\
\hline 20 m Sprint (m/sn) & 3,48 & 0,26 & 3,20 & 0,27 & 3,896 & $\mathbf{0 , 0 0 2} *$ \\
\hline 30 m Sprint (m/sn) & 4,74 & 0,14 & 4,61 & 0,08 & 5,972 & $0,000 *$ \\
\hline
\end{tabular}

Ort.= Ortalama; SS=Standart Sapma $* \mathrm{p}<0,05$

Tablo 4 incelendiğinde, denek grubuna ilişkin fiziksel parametreler gösterilmiştir. Karşılaştırma sonuçları incelendiğinde 12 haftalık egzersizin sonunda sağ el pençe kuvveti $(\mathrm{kg})$, sol el pençe kuvveti $(\mathrm{kg})$, sırt kuvveti $(\mathrm{kg})$, bacak kuvveti $(\mathrm{kg})$, dikey sıçrama $(\mathrm{cm})$, $\mathrm{VO}_{2}$ maks $(\mathrm{ml} / \mathrm{kg} / \mathrm{dk}), 10$ sprint $(\mathrm{sn})$ testi, $20 \mathrm{~m}$ sprint $(\mathrm{sn})$ testi ve $30 \mathrm{~m}$ sprint (sn) test değerlerinde istatistiksel olarak anlamlı farklılıklar tespit edilmiştir $(\mathrm{p}<0,05)$.

Tablo 5. Kontrol grubunun tanımlayıc1 parametreleri

\begin{tabular}{lcccccc}
\hline \multirow{2}{*}{ Değişkenler } & \multicolumn{2}{c}{ Ön Test (n=15) } & \multicolumn{2}{c}{ Son Test (n=15) } & \multirow{2}{*}{ t } & \multirow{2}{*}{ p } \\
\cline { 2 - 5 } & Ort & SS & Ort & SS & & \\
\cline { 1 - 5 } Yaş (Yıl) & 20,73 & 2,25 & 20,73 & 2,25 & & \\
Boy (cm) & 1,63 & 0,04 & 1,63 & 0,04 & $-1,000$ & 0,334 \\
Vücut Ağırlı̆̆ı (kg) & 60,57 & 3,57 & 61,24 & 3,39 & $-1,569$ & 0,139 \\
Spor yașı (Yıl) & 10,47 & 1,60 & 10,47 & 1,60 & $-1,432$ & 0,123 \\
VKİ (Vücut Kitle İndeksi) & 22,75 & 0,96 & 23,01 & 1,08 & $-1,689$ & 0,113 \\
\hline
\end{tabular}

Ort. = Ortalama; SS=Standart Sapma

Tablo 5 incelendiğinde, katılımcıların tanımlayıcı parametreleri gösterilmiştir. Buna göre Kontrol grubunun yaş ortalamaları $20,73 \pm 2,25 \mathrm{y} 1$, boy ortalamaları $1,63 \pm 0,04 \mathrm{~cm}$, spor yaş1 ortalamaları 10,47 $\pm 1,60$ yıl, vücut ağırlıkları ön test ortalamaları 60,57 $\pm 3,57 \mathrm{~kg}$, vücut ağırlıkları son test ortalamaları $61,24 \pm 3,39 \mathrm{~kg}$, VKİ ortalamaları 22,75 $\pm 0,96 \mathrm{~kg} / \mathrm{m}^{2}$, VKİ $23,01 \pm 1,08 \mathrm{~kg} / \mathrm{m}^{2}$ dir. Karş1laştırma sonuçlarına göre 12 haftalık egzersiz sonunda kontrol grubunun vücut ağırlıkları $(\mathrm{kg})$ ve $\mathrm{VKI}\left(\mathrm{kg} / \mathrm{m}^{2}\right)$ istatistiksel olarak anlamlı bir farklılık meydana gelmemiştir ( $\mathrm{p}>0,05)$.

Tablo 6. Kontrol grubunun çeviklik test parametreleri

\begin{tabular}{lcccccc}
\hline \multirow{2}{*}{ Değişkenler } & \multicolumn{2}{c}{ Ön Test $(\mathbf{n}=\mathbf{1 5})$} & \multicolumn{2}{c}{ Son Test $(\mathbf{n}=\mathbf{1 5})$} & \multirow{2}{*}{ t } & \multirow{2}{*}{$\mathbf{p}$} \\
\cline { 2 - 5 } & Ortalama & SS & Ortalama & SS & & \\
\hline Codat Test (m/sn) & 6,15 & 0,23 & 6,19 & 0,2 & $-1,89$ & 0,080 \\
T test $(\mathbf{m} / \mathbf{s n})$ & 10,98 & 0,32 & 10,99 & 0,33 & $-0,087$ & 0,932 \\
İllinois Test (m/sn) & 16,57 & 0,48 & 16,53 & 0,51 & 0,644 & 0,530 \\
Pro-Agility (m/sn) & 6,38 & 0,26 & 6,39 & 0,16 & $-0,147$ & 0,885 \\
\hline
\end{tabular}

Ort. =Ortalama; $\mathrm{SS}=$ Standart Sapma

Tablo 6 incelendiğinde, bakıldığında katılımcıların çeviklik testlerinin ortalamaları gösterilmiştir. Kontrol grubun karşılaştırmaları sonucunda 12 haftalık egzersiz sonunda Codat 
(Yön değiştirme) testi $(\mathrm{m} / \mathrm{sn})$, T testi $(\mathrm{m} / \mathrm{sn})$, İllinois testi $(\mathrm{m} / \mathrm{sn})$, Pro-Agility testi $(\mathrm{m} / \mathrm{sn})$ sonuçlarında istatistiksel olarak düzeyinde anlamlı bir farklılık meydana gelmemiştir $(p>0,05)$.

Tablo 7. Kontrol grubuna ilişkin fiziksel parametreleri

\begin{tabular}{|c|c|c|c|c|c|c|}
\hline \multirow{2}{*}{ Değişkenler } & \multicolumn{2}{|c|}{ Ön Test (n=15) } & \multicolumn{2}{|c|}{ Son Test $(n=15)$} & \multirow[b]{2}{*}{$\mathbf{t}$} & \multirow{2}{*}{$\mathbf{p}$} \\
\hline & Ort & SS & Ort & SS & & \\
\hline Sağ El Kuvveti(kg) & 22,11 & 3,53 & 22,10 & 3,65 & 0,03 & 0,976 \\
\hline Sol El Kuvveti (kg) & 19,73 & 3,56 & 19,87 & 3,75 & $-0,407$ & 0,691 \\
\hline Sirt Kuvveti(kg) & 68,53 & 12,99 & 71,47 & 13,20 & $-3,446$ & $0,004 *$ \\
\hline Bacak Kuvveti (kg) & 70,21 & 15,29 & 73,64 & 21,13 & $-4,002$ & $0,004 *$ \\
\hline Dikey Sıçrama (cm) & 37,53 & 5,07 & 36,60 & 3,48 & 1,182 & 0,257 \\
\hline 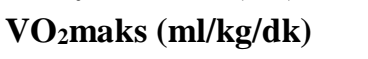 & 38,99 & 3,85 & 39,75 & 3,45 & $-0,669$ & 0,514 \\
\hline 10 m Sprint testi (m/sn) & 2,61 & 0,2 & 2,60 & 0,17 & 0,447 & 0,662 \\
\hline $20 \mathrm{~m}$ Sprint testi (m/sn) & 3,45 & 0,3 & 3,50 & 0,27 & $-1,844$ & 0,087 \\
\hline 30 m Sprint testi (m/sn) & 4,74 & 0,14 & 4,75 & 0,13 & $-0,69$ & 0,501 \\
\hline
\end{tabular}

Ort. $=$ Ortalama; $\mathrm{SS}=$ Standart Sapma; $* \mathrm{p}<0,05$

Tablo 7 incelendiğinde, kontrol grubuna ilişkin fiziksel parametreler gösterilmiştir. Karşılaştırma sonuçlarına göre 12 haftalık egzersiz sonunda sağ el pençe kuvveti (kg), sol el pençe kuvveti $(\mathrm{kg})$, dikey sıçrama $(\mathrm{cm}), \mathrm{VO}_{2}$ maks $(\mathrm{ml} / \mathrm{kg} / \mathrm{dk}), 10 \mathrm{~m}$ Sprint testi $(\mathrm{sn}), 20 \mathrm{~m}$ sprint testi (sn) ve $30 \mathrm{~m}$ sprint testi (sn) sonuçlarında istatiksel olarak anlamlı farklılık bulunmaz iken ( $\mathrm{p}>0,05)$; sırt kuvveti $(\mathrm{kg})$ ve bacak kuvveti $(\mathrm{kg})$ test sonuçlarına göre istatistiksel olarak anlamlı farklılık tespit edilmiştir $(\mathrm{p}<0,05)$.

Tablo 8. Denek ve kontrol grubunun çeviklik testlerinin ön ve son test karşılaştırmaları

\begin{tabular}{|c|c|c|c|c|c|}
\hline Değişkenler & $\mathbf{N}$ & Öntest & Ön test(p) & Son test & Son test(p) \\
\hline \multirow{2}{*}{ Codat test $(\mathrm{m} / \mathrm{sn})$} & $\mathrm{DG}=15$ & $6,24 \pm 0,30$ & \multirow{2}{*}{0,331} & $5,81 \pm 0,26$ & \multirow{2}{*}{$\mathbf{0 , 0 0 0 *}$} \\
\hline & $K G=15$ & $6,15 \pm 0,23$ & & $6,19 \pm 0,20$ & \\
\hline \multirow{2}{*}{$T$ test $(\mathrm{m} / \mathrm{sn})$} & $\mathrm{DG}=15$ & $10,93 \pm 0,40$ & \multirow{2}{*}{0,743} & $10,13 \pm 0,39$ & \multirow{2}{*}{$0,000^{*}$} \\
\hline & $\mathrm{KG}=15$ & $10,98 \pm 0,32$ & & $10,99 \pm 0,33$ & \\
\hline \multirow{2}{*}{ İllinois testi (m/sn) } & $\mathrm{DG}=15$ & $17,02 \pm 0,57$ & \multirow{2}{*}{$\mathbf{0 , 0 2 8 *}$} & $15,57 \pm 0,74$ & \multirow{2}{*}{$0,000 *$} \\
\hline & $\mathrm{KG}=15$ & $16,57 \pm 0,48$ & & $16,53 \pm 0,51$ & \\
\hline \multirow{2}{*}{ Pro- Agility testi (m/sn) } & $\mathrm{DG}=15$ & $6,25 \pm 0,36$ & \multirow{2}{*}{0,256} & $5,66 \pm 0,33$ & \multirow{2}{*}{$\mathbf{0 , 0 0 0} *$} \\
\hline & $K G=15$ & $6,38 \pm 0,26$ & & $6,39 \pm 0,16$ & \\
\hline
\end{tabular}

Ort= Ortalama; SS $=$ Standart Sapma; DG= Denek Grup; KG= Kontrol Grup *p $<0,05$

Tablo 8'de denek ve kontrol gruplarının çeviklik testlerinin ön ve son test sonuçlarının karşılaştırılması sunulmuştur. Her iki grubun ön test karşılaştırmaları incelendiğinde 12 haftalık egzersizin öncesinde illinois testinde $(\mathrm{m} / \mathrm{sn})$ istatistiksel olarak anlamlı farklılık meydana gelirken $(\mathrm{p}<0,05)$; her iki grubun son test karşılaştırmaları incelendiğinde egzersizlerin sonunda codat (yön değiştirme) testi $(\mathrm{m} / \mathrm{sn}), \mathrm{t}$ test $(\mathrm{m} / \mathrm{sn})$ ve pro-agility testi $(\mathrm{m} / \mathrm{sn})$ sonucunda istatistiksel olarak anlamlı farklılık meydana gelmiştir $(\mathrm{p}<0,05)$. 
Öztürk, B., ve Taş, M. (2020). Kadın futbolcularda 12 haftalık Kettlebell antrenmanlarının bazı fiziksel ve fizyolojik parametreler üzerine etkilerinin incelenmesi. Spor Bilimleri Araştırmaları Dergisi, 5(2), 143-158.

Tablo 9. Denek ve kontrol grubuna ilişkin fiziksel parametrelerinin ön ve son test karşılaştırmaları

\begin{tabular}{|c|c|c|c|c|c|}
\hline Değişkenler & $\mathbf{N}$ & Ön test & Ön test (p) & Son test & Son test (p) \\
\hline \multirow{2}{*}{ Sağ El Kuvveti (kg) } & $\mathrm{DG}=15$ & $23,85 \pm 3,29$ & \multirow{2}{*}{0,174} & $28,43 \pm 4,45$ & \multirow{2}{*}{$0,000^{*}$} \\
\hline & $\mathrm{KG}=15$ & $22,11 \pm 3,53$ & & $22,10 \pm 3,65$ & \\
\hline \multirow{2}{*}{ Sol El Kuvveti (kg) } & $\mathrm{DG}=15$ & $21,75 \pm 4,07$ & 0,159 & $25,81 \pm 5,06$ & \multirow{2}{*}{$\mathbf{0 , 0 0 1 *}$} \\
\hline & $\mathrm{KG}=15$ & $19,73 \pm 3,56$ & \multirow{3}{*}{0,257} & $19,87 \pm 3,75$ & \\
\hline \multirow{2}{*}{ Sirt Kuvveti (kg) } & $\mathrm{DG}=15$ & $74,26 \pm 14,15$ & & $84,28 \pm 11,46$ & \multirow{2}{*}{0,008} \\
\hline & $\mathrm{KG}=15$ & $68,53 \pm 12,99$ & & $71,47 \pm 13,20$ & \\
\hline \multirow{2}{*}{ Bacak Kuvveti (kg) } & $\mathrm{DG}=15$ & $70,21 \pm 15,29$ & \multirow{2}{*}{0,234} & $87,21 \pm 9,65$ & \multirow{2}{*}{0,006} \\
\hline & $K G=15$ & $71,87 \pm 11,23$ & & $73,64 \pm 21,13$ & \\
\hline \multirow{2}{*}{ Dikey Sıçrama (cm) } & $\mathrm{DG}=15$ & $37,13 \pm 4,22$ & \multirow{2}{*}{0,816} & $42,13 \pm 4,27$ & \multirow{2}{*}{$0,001^{*}$} \\
\hline & $\mathrm{KG}=15$ & $37,53 \pm 5,07$ & & $36,60 \pm 3,48$ & \\
\hline \multirow{2}{*}{ VO2maks ( $\mathrm{ml} / \mathrm{kg} / \mathrm{dk})$} & $\mathrm{DG}=15$ & $38,24 \pm 5,06$ & \multirow{2}{*}{0,653} & $44,81 \pm 4,73$ & \multirow{2}{*}{$0,002^{*}$} \\
\hline & $\mathrm{KG}=15$ & $38,99 \pm 3,85$ & & $39,75 \pm 3,45$ & \\
\hline \multirow{2}{*}{10 m Sprint (m/sn) } & $\mathrm{DG}=15$ & $2,50 \pm 0,18$ & \multirow{2}{*}{0,125} & $2,24 \pm 0,16$ & \multirow{2}{*}{$\mathbf{0 , 0 0 0}$} \\
\hline & $K G=15$ & $2,61 \pm 0,20$ & & $2,60 \pm 0,17$ & \\
\hline \multirow{2}{*}{20 m Sprint (m/sn) } & $\mathrm{DG}=15$ & $3,48 \pm 0,26$ & \multirow{2}{*}{0,746} & $3,20 \pm 0,27$ & \multirow{2}{*}{$0,005^{*}$} \\
\hline & $\mathrm{KG}=15$ & $3,45 \pm 0,30$ & & $3,50 \pm 0,27$ & \\
\hline \multirow{2}{*}{30 m Sprint (m/sn) } & $\mathrm{DG}=15$ & $4,74 \pm 0,14$ & \multirow{2}{*}{0,969} & $4,61 \pm 0,08$ & \multirow{2}{*}{$\mathbf{0 , 0 0 1}{ }^{*}$} \\
\hline & $K G=15$ & $4,74 \pm 0,14$ & & $4,75 \pm 0,13$ & \\
\hline
\end{tabular}

Ort.=Ortalama; SS= Standart Sapma; DG= Denek Grup; Kontrol Grubu= Kontrol Grup*p<0,05

Tablo 9 incelendiğinde, denek ve kontrol gruplarına ilişkin fiziksel parametrelerin ön ve son test karşılaştırmaları gösterilmiştir. Her iki grubun ön test karşılaştırmaları incelendiğinde 12 haftalık egzersiz öncesinde istatistiksel olarak anlamlı bir farklılık meydana gelmemişken ( $>0,05)$, her iki grubun son test karşılaştırmaları incelendiğinde egzersiz sonunda sağ el pençe kuvveti $(\mathrm{kg})$, sol el pençe kuvveti $(\mathrm{kg})$, sırt kuvveti $(\mathrm{kg})$, bacak kuvveti $(\mathrm{kg})$, dikey sıçrama $(\mathrm{cm}), \mathrm{VO}_{2}$ maks $(\mathrm{ml} / \mathrm{kg} / \mathrm{dk}), 10 \mathrm{~m}$ sprint $(\mathrm{m} / \mathrm{sn}), 20 \mathrm{~m}$ sprint $(\mathrm{m} / \mathrm{sn})$ ve $30 \mathrm{~m}$ sprint $(\mathrm{m} / \mathrm{sn})$ sonucunda istatistiksel olarak anlamlı farklılıklar meydana gelmiştir $(p<0,05)$.

\section{TARTIŞMA VE SONUÇ}

Futbol; kuvvet, sürat, güç, yön değiştirme, sıçrama, denge, çalım ve şut gibi yüksek yoğunluklu ve aralıklı becerilerden oluşan bir spor dalı olmasından dolayı her mevkide oynayan futbolcuların fiziksel, fizyolojik, biomotorik, psiko-mental, teknik özelliklerinin yüksek seviyede olması gerekmektedir (Günay, Sevim, Savaş ve Erol, 1994).

Kadın futbolcularda uygulanan 12 haftalık kettlebell antrenman programı sonucunda elde edilen verilere bakıldığında; denek grubunun 12 haftalık kettlebell antrenmanı sonrasında vücut ağırlığı ve VKİ değerlerinde istatistiksel olarak anlamlı bir artış görülürken kas kütlesinde istatistiksel olarak anlamlı bir farklılık elde edilmemiştir. Kontrol grubunda ise vücut ağırlığı ve VKİ değerlerinde istatistiksel olarak anlamlı bir artış olmadığı tespit edilmiştir. Gruplar arası farka bakıldığında ise iki grubunda ön ve son test değerleri karşılaştırıldığında istatistiksel olarak anlamlı bir farklılık gözlemlenmemiştir. Jay vd., (2011) yaptıkları çalışmada, 8 haftalık kettlebell antrenmanı sonucunda vücut kas kitlesinde \%19,6 artış olduğunu tespit etmişlerdir. Palmieri-Smith, Villwock, Downie, Hecht ve Zernicke (2013) erkek sporculara 10 haftalık crossfit tabanlı yüksek yoğunluklu yaptırdıkları kuvvet 
antrenmanları sonucunda vücut kas kütlesinde artış, vücut yağ yüzdesinde azalma ve VKİ değerlerinde anlamlı bir artış gözlemlenmemiştir. Buna ek olarak genç erkek sporcularda 8 hafta boyunca yüksek yoğunluklu ve aralıklı kuvvet antrenmanlarının kas kütlesindeki artışlar vücut kütlesinin artışı ile açıklanabilmektedir (Musa, Adeniran, Dikko ve Sayers, 2009). Yukarıdaki çalışmalara bakıldığında kas kütlesinde bir artış gözlemlenirken, kuvvet değerlerinde de bir artış olduğu bildirilmektedir. Bu çalışma sonuçları kuvvet değerleri ve kas kütlesinin artışı bakımından çalışmamızın sonuçları ile örtüşmektedir. Bu çalışmalardan farklı olarak Otto, Coburn, Brown ve Spiering (2012) erkek güreşçilerde bir buçuk ay boyunca haftada 2 defa uygulanan kettlebell antrenman programı sonrasında kas hacminde, kas kütlesinde ve antropometrik değerlerinde herhangi bir farklılık olmadığını ancak sıçrama düzeylerinde artış görüldüğünü belirtmişlerdir. Buna ek olarak Meier, Quednow ve Sedlak (2015) kadın ve erkek sporcuların farklı şiddette ve tekrar sayılarında 5 hafta boyunca haftada 2 kere uygulanan kettlebell antrenmanlarının vücut kas kütlesi ve kuvvet değerlerinde farklılık olmadığını belirtmişlerdir. Literatür incelendiğinde kettlebell antrenmanlarının kas kütlesini ve yağsız kas kütlesinde artış sağladığı bildirilmektedir (Jay vd., 2011). Otto, Coburn, Brown ve Spiering (2012) ile Meier, Quednow ve Sedlak (2015) çalışmalarında kas kütlesinde artış olmamasının ve kuvvet değerlerinde gelişme sağlanmamasının sebebinin, bu çalışmadan farklı olarak egzersiz süreci, egzersiz tekrar sayısı ve şiddetinin farklılık göstermesinden kaynaklandığı düşünülebilir.

Kettlebell egzersizlerinin doğası balistiktir ve balistik tip hareketlerle yapılan antrenmanların maksimum patlayıcı gücü ve kuvvet geliştirme oranını arttırdığını bildirilmiştir (Winchester vd., 2008). Bu antrenman programı sürecinde patlayıcı güç egzersizleri yapmak için kullanılan büyük kas grupları, gösterilen kuvvet ve gücün aktarımını açıklamaya yardımcı olabilir. Manocchia vd., (2013) yaptıkları çalışma, kettlebell antrenmanlarının patlayıcı gücü etkilemesinde ve maksimal kuvvetin performansa etkisinin olup olmayacağını inceleyen ilk çalışmalar arasında görülmektedir. Bununla birlikte, patlayıcı gücü ve diğer kuvvet egzersizlerinin performansı geliştirmesinde yüksek oranda ilişkili olduğunu destekleyen veriler bulunmaktadır (Baker ve Newton, 2008; Cormie, McGuigan ve Newton, 2010).

Yapılan çalışmada 12 haftalık kettlebell antrenmanı sonrasında kadın futbolcularda kuvvet değerlerinde istatistiksel olarak anlamlı bir farklılık görülmektedir $(\mathrm{p}<0,05)$. Literatür incelendiğinde çalı̧̧mamızın sonucunu destekleyen çalışmalar görülmüştür. Halter sporcuları ve sağlıklı erkek sporcularda iki grup halinde yapılan 10 haftalık kettlebell antrenmanın sonucunda üst ekstremite bölgesinde anlamlı farkl1lıklar olduğu rapor edilmiştir (Manocchia vd., 2013). Diğer bir çalışmada ise Meier, Quednow ve Sedlak (2015) kolej öğrencilerinde 5 haftalık kettlebell antrenman sonucunda sağ el kuvvetinin sol el kuvvetinden fazla olduğunu gözlemlemiş̧tir. Bunun sebebini de sağ elin gücünün sol elin gücüne göre daha baskın (dominant) olmasından kaynaklı olduğunu bildirmiştir. Buna ek olarak sağlıklı ve spor yapan kadınlarda kettlebell egzersizleri içerisinde bulunan Turkish get-up hareketinin üst ekstremiteyi geliştirdiğini gösteren bir çalışmada kol kuvvetinde önemli ölçüde artı̧̧ olduğu tespit edilmiştir (Leatherwood, Whittaker ve Esco, 2014). Yukarıdaki çalışmalara bakıldığında kuvvet değerlerinde artış olduğu gözlemlenmektedir. Mevcut çalışma sonuçları literatürle paralellik göstermektedir. 
Literatürdeki diğer çalışmalara bakıldığında, Maulit vd., (2017) 23-24 yaş arası erkek sporcuların 4 haftalık kettlebell antrenmanları ve deadlift egzersizleri ile iki grubun kendi aralarında karşılaştırılması sonucunda sırt ve bacak kuvvetlerinde artış görülmüştür. Ancak her iki grup arasında ön test ve son test değerleri karşılaştırıldığında anlamlı bir farklılık gözlemlenmemiştir. Buna ek olarak egzersiz şiddeti bakımından farklılık gösteren Eckert ve Snarr (2016) çalışmasında, kadın ve erkek sporcularda yapılan 6 haftalık kettlebell antremanı sonucunda sırt ve bacak kuvvetlerinde anlamlı bir artış olduğu tespit edilmiştir. Bu durum çalışmaya katılan sporcuların maksimal kuvvetlerinin gelişmesinde egzersiz şiddetinin fazla olması ile açıklanabilir. Yapılan çalışmalara göre kettlebell antrenmanlarının dikey sıçrama değerleri üzerine etkisi incelendiğinde, sıçrama seviyesinde ve bacak kuvvetinde anlamlı bir artış olduğu gözlemlenmiştir (Otto, Coburn, Brown ve Spiering, 2012).

Futbol yapısı gereği sürekli olarak reaksiyon özelliğinin iyi olması, yön değişikliklerinin bol olduğu ve süratin son derece önemli olduğu bir branştır. Her bir mevkide oynayan sporcunun ani yön değiştirmeleri ve zaman zaman görev alanlarının dışında da hareket etmeleri beklenmektedir. Savunma ve hücum oyuncuları gerektiğinde birbirlerine yardımcı olmalıdır (Taş vd., 2013). Yapılan çalışmada 12 haftalık kettlebell antrenmanı sonucunda denek ve kontrol grubunun her ikisinde çeviklik değerlerinde anlamlı farklılıklar gözlemlenmiştir. Her iki grubun ön test karşılaştırmalarında sadece illinois test parametresinde farklılık görünürken, son test değerlerinin karşılaştırılmasında diğer çeviklik test parametrelerinde de bir artış olduğu tespit edilmiştir. Bu durumun katılımcıların antrenman geçmişi veya antrenman yüklerinin faklı olması nedeniyle test değerlerindeki farklılıkların ortaya çıkması şeklinde yorumlanabilir ancak denek grubundaki artışın kontrol grubuna göre daha yüksek olması kuvvet antrenmanlarının kadın futbolcularda performansa olumlu yönde etki etmesinden kaynaklanabilir. Ayrıca 12 haftalık kettlebell antrenman programı sonrasında denek ve kontrol grubunda; codat test, $\mathrm{t}$ test, pro agility test ve illinois test değerlerinde grup içi farklılıklara bakıldığında, kontrol grubunda istatistiksel olarak herhangi bir artış gözlemlenmezken, denek grubunda istatistiksel olarak anlamlı farklılıklar olduğu tespit edilmiştir. Gruplar arası farklar incelendiğinde ise iki grubun çeviklik değerlerinde istatistiksel olarak anlamlı farklılı̆̆ın olduğu gözlenmiştir.

Hazır, Mahir ve Açıkada (2010), genç erkek futbolcularda çeviklik ve reaksiyon sürati ile ilgili yaptıkları çalışmasında, çeviklik değerlerinde anlamlı bir farklılık olduğunu gözlemlemişlerdir. Çoban'ın (2017) çalışmasında kadın futbolcularda çeviklik ve reaksiyon parametreleri incelendiğinde, 1. Lig kadın futbolcuların zig zag koşularında bir artış görünürken, 2. Lig kadın futbolcularında istatistiksel olarak anlamlı bir artışın olmadı̆̆ futbolcularda 32 haftalık kuvvet antrenmanı programı sonucunda çeviklik ve sürat parametrelerinde anlamlı olarak farklılık meydana gelmediği gözlemlenirken, genç erkek sporcuların katıldığı kettlebell antrenman grubunun değerlerinde ise anlamlı olarak artışlar tespit edilmiştir (Kruszewski vd., 2017). Yapılan çalışmaların sonuçları ile mevcut çalışma sonuçları arasında benzerlikler gözlemlenmektedir.

Yapılan bu araştırma sonucunda elde edilen sonuçlardan biri de 12 haftalık kettlebell antrenmanı sonrasında $\mathrm{VO}_{2}$ maks değerlerinde istatistiksel olarak anlamlı bir artış görülmesidir. Gruplar arası farka bakıldığında ise iki grubunda ön test ve son test değerleri karşılaştırıldığında istatistiksel olarak anlamlı bir farklılık elde edilmiştir. Falatic vd., (2015) ulusal kolej takımındaki kadın futbolcularla 4 hafta boyunca haftada 2 defa uygulanan kettlebell antrenmanı 
sonucunda aerobik kapasitede artış olduğu belirtmiştir. Buna ek olarak Fung ve Shore (2010), sağlıklı olarak spor yapan kadınların kettlebell antrenmanı sonunda $\mathrm{VO}_{2}$ maks değerlerinde anlamlı olarak bir artış olduğunu gözlemlemişlerdir. Ayrıca çalışmaya katılan kadınların anaerobik değerlerinde istatistiksel olarak herhangi bir farklılık olmadığ 1 da tespit edilmiştir. $\mathrm{Bu}$ çalışmadan egzersiz süresi ve şiddeti bakımından farklılık gösteren Helgerud vd., (2007) çalışmasında erkek futbolcularda yüksek yoğunluklu interval antrenmanların \%90-95 şiddetinde olan egzersizler sonucunda $\mathrm{VO}_{2}$ maks değerinde artış görüldüğü, ayrıca futbolcuların performans düzeylerini arttırdığını da bildirmiştir. Literatürde geçen bu çalışma ile bizim yapmış olduğumuz çalışma arasında paralellik gözükmektedir. Bu çalışmalardan farklı olarak Farrar, Mayhew ve Koch (2010) ile Jay vd., (2011) yaptıkları çalışmalarda kettlebell antrenmanı sonrasında aerobik kapasite ve kardiyovasküler sistemde herhangi bir artış olmadığını belirtmişlerdir. $\mathrm{Bu}$ çalışmaların sonuçları mevcut araştırma sonuçları ile uyuşmamaktadır. Yapılan bu çalışmaların, mevcut çalışmadan farklılık göstermesinin yaş ortalamasının yüksek olması ve antrenman metodların farklı olmasının kardiyovasküler sistemin iyileşmesinde etkisinin olmadığını işaret ettiği söylenebilir.

Bu çalışmada 12 haftalık kettlebell antrenman süresi boyunca kontrol grubunun sürat değerlerinde istatistiksel olarak bir artış görülmezken, denek grubunun antrenman sonucunda sürat değerlerinde istatistiksel olarak anlamlı artış olduğu gözlemlemiştir. Her iki grubun ön test ve son test değerleri karşılaştırıldığında ise istatistiksel olarak anlamlı farklılık olduğu bildirilmiştir. Vescovi, Brown ve Murray, (2007) farklı branşlarda bulunan kadın sporcuların kuvvet antrenmanı sonrasında, sürat değerlerinde anlamlı olarak farklılık olduğunu belirtmişlerdir.

Sonuç olarak; düzenli uygulanan kettlebel antrenmanlarının, bazı fiziksel ve fizyolojik parametrelerin gelişimine katkı sağladığı söylenebilir. Ayrıca, antrenörlere, sporculara ve kondisyonerlere bu antrenman metodunu uygulayabilecekleri önerilebilir. 
Öztürk, B., ve Taş, M. (2020). Kadın futbolcularda 12 haftalık Kettlebell antrenmanlarının bazı fiziksel ve fizyolojik parametreler üzerine etkilerinin incelenmesi. Spor Bilimleri Araştırmaları Dergisi, 5(2), 143-158.

\section{KAYNAKLAR}

Acar, M.F. (2000). Kuramsal boyutlarıyla antrenman bilimi el kitabı. İzmir: Meta Basım.

Açıkada, C., Özkara, A., Hazır, T., Aşçı, A., Turnagöl, H., Tınazcı, C. ve Ergen, E. (1996). Bir futbol takımında sezon öncesi hazırlık antrenmanlarının bir kısım kuvvet ve dayanıklılık özellikleri üzerine etkisi. Spor Bilimleri Dergisi, 7(1), 24-32.

Agostini, R. (1994). Medical and orthopedic issues of active and athetic women. Philadelphia: Hanley \& Belfus Inc.

Albay, M.D., Tutkun, E., Ağaoğlu, Y.S., Canikli, A. ve Albay, F. (2008). Hentbol, voleybol ve futbol üniversite takımlarının bazı motorik ve antropometrik özelliklerinin incelenmesi. Spormetre, 6(1), 13-20.

Arnason, A., Sigurdsson, S.B., Gudmundsson, A., Holme, I., Engebretsen, L. \& Bahr, R. (2004). Physical fitness, injuries, and team performance in soccer. Med Sci Sports Exercise, 36(2), 278-285. https://doi.org/10.1249/01.MSS.0000113478.92945.CA.

Baker, D. \& Nance, S. (1999). The relation between running speed and measures of strength and power in professional rugby league players. The Journal of Strength \& Conditioning Research, 13(3), 230-235.

Baker, D.G.,\& Newton, R.U. (2008). Comparison of lower body strength, power, acceleration, speed, agility, and sprint momentum to describe and compare playing rank among professional rugby league players. The Journal of Strength \& Conditioning Research, 22(1), 153-158. https://doi.org/10.1519/JSC.0b013e31815f9519.

Bangsbo, J. \& Michalsik, L. (2002). Assessment of the physiological capacity of elite soccer players. In T. Reilly, \& A. Murphy (Eds.), Science and football IV (pp. 53-62). Cambridge, UK: Routledge.

Bayraktar, I. (2013). Elit boksörlerin çeviklik, sürat, reaksiyon ve dikey sıçrama yetileri arasındaki ilişkiler. Akademik Bakış Dergisi, 35, 1-8.

Bizzini, M., Junge, A., Bahr, R. \& Dvorak, J. (2011). Injuries of football referees: A Representative survey of Swiss referees officiating at all levels of play. Scandinavian Journal of Medicine \& Science in Sports, 21(1), 42-47. https://doi.org/0.1111/j.1600-0838.2009.01003.x.

Cometti, G., Maffiuletti, N.A., Pousson, M., Chatard, J.C. \& Maffulli, N. (2001). Isokinetic strength and anaerobic power of elite, subelite and amateur French soccer players. International Journal of Sports Medicine, 22(01), 45-51. https://doi.org/ 10.1055/s-2001-11331.

Cormie, P., McGuigan, M.R. \& Newton, R.U. (2010). Adaptations in athletic performance after ballistic power versus strength training. Medicine \& Science in Sports \& Exercise, 42(8), 15821598. https://doi.org/10.1249/mss.0b013e3181d2013a.

Çoban, C. (2017). Farklı liglerdeki kadın futbolcuların reaksiyon ve çeviklik testlerinin karşılaştırılması. Yüksek Lisans tezi, Manisa Celal Bayar Üniversitesi, Sağlık Bilimleri Enstitüsü, Spor Sağlık Bilimleri Anabilim Dalı, Manisa.

Eckert, R.M. \& Snarr, R.L. (2016). Kettlebell Training: A Brief Review. J Sport Hum Perform, 4(3), 1-10.

Eniseler, N. (2010). Bilimin ışı̆̆ında futbol antrenmanı. İzmir: Birleşik Matbaacılık.

Falatic, J.A., Plato, P.A., Holder, C., Finch, D., Han, K. \& Cisar, C.J. (2015). Effects of kettlebell training on aerobic capacity. The Journal of Strength \& Conditioning Research, 29(7), 1943-1947. https://doi.org/10.1519/JSC.0000000000000845.

Farrar, R.E., Mayhew, J.L. \& Koch, A.J. (2010). Oxygen cost of kettlebell swings. J Strength Cond Res, 24(4), 1034-1036. https://doi.org/10.1519/JSC.0b013e3181d15516.

Fung, B.J., \& Shore S.L. (2010). Aerobic and anaerobic work during kettlebell exercise: A pilot study. Med Sci Sports Exercise, 42(5), 834. https://doi.org/10.1249/01.MSS.0000386575.49791.be. 
Öztürk, B., ve Taş, M. (2020). Kadın futbolcularda 12 haftalık Kettlebell antrenmanlarının bazı fiziksel ve fizyolojik parametreler üzerine etkilerinin incelenmesi. Spor Bilimleri Araştırmaları Dergisi, 5(2), 143-158.

Günay, M., Sevim, Y., Savaş, S. ve Erol, A.E. (1994). Pliometrik çalışmaların sporcularda vücut yapısı ve sıçrama özelliklerine etkisi. Spor Bilimleri Dergisi, 6(2), 38-45.

Günay, M. ve Yüce, İ.A. (2001). Futbol antrenmanının bilimsel temelleri (İkinci Baskı). Ankara: Gazi Kitabevi.

Haugen, T. (2014). The Role and development of sprinting speed in soccer. Human Kinetics Journals, 9(3), 432441. https://doi.org/10.1123/IJSPP.2013-0121.

Hazır, T., Mahir, Ö.F. ve Açıkada, C. (2010). Genç futbolcularda çeviklik ile vücut kompozisyonu ve anaerobik güç arasındaki iliş̧i. Spor Bilimleri Dergisi, 21(4), 146-153.

Helgerud, J., Hoydal, K., Eivind, W., Karlsen, T., Berg, P., Bjerkaas, M., Simonsen T., Helgesen C., Hjorth, N., Bach R. \& Hoff, J. (2007). Aerobic high-intensity intervals improve $\mathrm{VO}_{2} \mathrm{max}$ more than moderate training. Medicine \& Science in Sports \& Exercise, 39(4), 665-671. https://doi.org/10.1249/mss.0b013e3180304570.

Holmberg, P. (2009). Agility training for experienced athletes: A dynamical system approach. Strength Conditioning Journal, 31(5), 73-78. https://doi.org/10.1519/SSC.0b013e3181b988f1.

Jay, K., Frisch, D., Hansen, K., Zebis, M.K., Anderse, C.H., Mortensen, O.S. \& Andersen, L.L. (2011). Kettlebell training for musculoskeletal and cardiovascylar health. Scand J Work, Envir \& Health, 37(3), 196-203. https://doi.org/10.2307/41151543.

Karacabey, K. (2013). Sporda performans ve çeviklik testleri. International Journal of Human Sciences, 10(1), 1693-1704.

Köklü, Y., Özkan, A. ve Ersöz, G. (2009). Futbolda dayanıklılık performansının değerlendirilmesi ve geliştirilmesi. CBÜ Beden Eğitimi ve Spor Bilimleri Dergisi, 4(3), 142-150.

Kruszewski, M., Kruszewski, A., Kuźmicki, S., Korczak, R., Tabęcki, R., Landowski, L. \& Sitek, P. (2017). The effectiveness of kettlebell exercises in the aspects of special efficiency training in American football. Baltic J Health Phys Act, 9(3),53-62. https://doi.org/10.29359/BJHPA.09.3.05.

Leatherwood, M.D., Whittaker, A. \& Esco, M.R. (2014). Exercise technique: The Turkish get-up with a $\begin{array}{llll}\text { kettlebell. Strength \& } \quad \text { Conditioning Journal, } & \text { 36(6), }\end{array}$ https://doi.org/10.1519/SSC.0000000000000096.

Little, T. \& Williams, A.G. (2006). Effects of differential stretching protocols during warm-ups on high speed motor capacities in professional soccer players. Journal of strength and conditioning research, 20(1), 203-7. https://doi.org/10.1519/R-16944.1.

Loturco, I., Pereira, L.A., Moraes, J.E., Kitamura, K., Abad, C.C.C., Kobal, R. \& Nakamura, F.Y. (2017). Jumpsquat and half-squat exercises: selective influences on speed-power performance of elite rugby sevens players. PloS one, 12(1),1-11. https://doi.org/10.1371/journal.pone.0170627.

Mackenzie, R. \& Cushion, C. (2013). Performance analysis in football: A critical review and implications for future research. Society of Health and Physical Educators, 31(6), 639-676. https://doi.org/10.1080/02640414.2012.746720.

Manocchia, P., Spierer, D.K., Lufkin, A.K., Minichiello, J. \& Castro, J. (2013). Transference of kettlebell training to strength, power and endurance. J Strength Cond Res, 27, 477-484. https://doi.org/10.1519/JSC.0b013e31825770fe.

Maulit, M.R., Archer, D.C., Leyva, W.D., Munger, C.N., Wong, M.A., Brown, L.E. \& Galpin, A.J. (2017). Effects of kettlebell swing vs. explosive deadlift training on strength and power. International Journal of Kinesiology and Sports Science, 5(1), 1-7. http://dx.doi.org/10.7575//aiac.ijkss.v.5n.1p.1.

Meier, J., Quednow, J. \& Sedlak, T. (2015). The effects of high intensity interval-based kettlebells and battle rope training on grip strength and body composition in college aged adults. International Journal of Exercise Science, 8(2), 124-133. 
Musa, D.I., Adeniran, S.A., Dikko, A.U. \& Sayers, S.P. (2009). The effect of a high-intensity interval training program on high-density lipoprotein cholesterol in young men. J Strength Cond Res, 23(2), 587-592. https://doi.org/10.1519/JSC.0b013e318198fd28.

Otto, W.H., Coburn, J.W., Brown, L.E. \& Spiering, B.A. (2012). Effects of weightlifting vs. kettlebell training on vertical jump, strength and body composition. Journal of Strength and Conditioning Research, 26(5), 1199-1202. https://doi.org/10.1519/JSC.0b013e31824f233e.

Palmieri-Smith, R.M., Villwock, M., Downie, B., Hecht, G. \& Zernicke, R. (2013). Pain and effusion and quadriceps activation and strength. Journal of Athletic Training, 48(2), 186-191. https://doi.org/10.4085/1062-6050-48.2.10.

Reilly, T., Bangsbo, J. \& Franks, A. (2000). Anthropometric and physiological predispositions for elite soccer. Journal of Sport Sciences, 18(9), 669-683. https://doi.org/10.1080/02640410050120050.

Sheppard, J.M. \& Young, W. (2006). Agility literatüre review: Classifications, training and testing. Journal of Sports Sciences, 24(9), 919 - 932. https://doi.org/10.1080/02640410500457109.

Taş, M., Sevim, O., Özkan, A., Akyüz, M., Akyüz, Ö. ve Uslu, S. (2013). Yıldız basketbol milli takımında yer alan kız sporcuların anaerobik performans ve kuvvet değerlerinin belirlenmesinde çevresel ölçümlerden elde edilen bazı değerlerin rolü. International Journal of Science Culture and Sport, 1(3), 14-23.

Vescovi, J.D., Brown, T.D. \& Murray, T.M. (2007). Descriptive characteristics of NCAA Division I women lacrosse players. Journal of Science and Medicine in Sport, 10(5), 334-340. https://doi.org/10.1016/j.jsams.2006.07.010.

Winchester, J.B., McBride, J.M., Maher, M.A., Mikat, R.P., Allen, B.K., Kline, D.E. \& McGuigan, M.R. (2008). Eight weeks of ballistic exercise improves power independently of changes in strength and muscle fiber type expression. J Strength Cond Res, 22, 1728-1734. https://doi.org/10.1519/JSC.0b013e3181821abb.

Bu eser Creative Commons Atıf-GayriTicari 4.0 Uluslararası Lisansı ile lisanslanmıştır. 